\title{
Couples' joint decision-making: the construction and validation of a key proxy for understanding gender relations in contemporary families
}

\author{
Maira Covre-Sussai ${ }^{\star \star}$
}

Gender relations have become a key dimension in family studies, and understanding gender relations as both determining and resulting from outcome of new family configurations requires the use of specific surveys aimed at the dynamics of couples. Unfortunately, nationally representative surveys of this type are not available for Latin American countries. Nonetheless, the most recent versions of the Demographic and Health Surveys (DHS) include a section called “Women's Status and Empowerment", which can provide information about gender relations as well. This study aims at assessing the construct of gender relations in terms of couples' joint decision-making for all five Brazilian geographical regions. To this end, a step-by-step multi-group confirmatory factor analysis (MGCFA) was applied in order to verify whether this concept can be compared across Brazilian regions. Results show that the DHS items can be used reliably for measuring couples' joint decision-making and that this construct can be meaningfully compared over the regions. These findings will contribute to further demographic and sociological research on gender relations which can use this concept and other indicators provided by the DHS to identify the causal processes related to it.

Keywords: Gender relations. Joint decisions. Multiple Group Confirmatory Factor Analysis (MGCFA). Measurement invariance.

\footnotetext{
* In this article the term family refers to heterosexual couples living together with or without children or civil registration. ** University of Leuven, Leuven, Belgium (mairacovre@gmail.com).
} 


\section{Introduction}

Family formation patterns have witnessed noticeable changes in Western countries since the 1960s. With the increasing incidence of divorce and greater social acceptance of non-marital cohabitation, marriage is no longer considered the only way to establish a family. Statistics indicate that Brazil follows these Western trends with its growing divorce and cohabitation rates. According to the Brazilian Census Bureau (IBGE), the divorce rate in Brazil has increased by 300\% since the 1970s. In 2010, 36.4\% of Brazilian couples were cohabiting out of wedlock, while the figure for 1960 had been only $6.45 \%$ (IBGE, 2010). These changes in nuptiality patterns, such as increasing cohabitation, postponement of marriage, and decreases in fertility are interpreted by sociologists and demographers as consistent with shifts in the ideational domain, meaning values and beliefs, as well as increasing gender symmetry (LESTHAEGHE; SURKYN, 1988).

Recent socioeconomic indicators demonstrate increasing gender symmetry in Brazilian society. While the total fertility rate decreased from 6 to 1.9 births per woman between 1960 and 2010 (IBGE, 2010), women's participation in the labor force increased from approximately 31 percent in the 1980s (WORLD BANK, 2010) to over 45 percent in 2011 (IBGE, 2012). Women's gross enrolment in higher learning rose from 14.6 to 39 percent between 1998 and 2008 (WORLD BANK, 2010). Previous studies also show that, since the 1990s, women in Brazil have attained higher levels of formal education than men (e.g. BELTRÃO; ALVES, 2009; ESTEVE et al., 2012), although the subordination of women to men is still very noticeable in several aspects of social life (ENGUITA, 1996; ROSEMBERG, 2001, 2002; GUEDES, 2004). For instance, studies indicate that working women earn less than men (MONTALI, 2004) and are nevertheless the main persons responsible for household labor and childcare (SOARES, 2008; SORJ et al., 2007).

While higher postponement of marriage, decreasing fertility and increasing cohabitation are relatively easy to measure with available data (e.g. demographic censuses), the same cannot be said of the social forces behind this phenomenon. The study of gender relations inside families, for example, requires the use of specific surveys aiming at dynamics of couples. Unfortunately, nationally representative surveys of this type are not available for Latin American countries (RODRÍGUEZ-VIGNOLI, 2005), including Brazil. However, the most recent versions of the Demographic and Health Surveys (DHS) include a section on "Women's Status and Empowerment," which can provide information about gender relations as well. The main goals of this study are (i) to identify whether it is possible to assess a construct that measures joint decision-making by couples through the questions asked in the section entitled "Women's Status and Empowerment” of the Brazilian DHS-2006 (in Portuguese, PNDS-2006); ${ }^{1}$ and (ii) to verify whether this information is comparable among the five geographical regions in Brazil. ${ }^{2}$

\footnotetext{
${ }_{1}^{1}$ The Brazilian DHS is called 'Pesquisa Nacional de Demografia e Saúde (PNDS)' and can be found here: http://bvsms. saude.gov.br/bvs/pnds/index.php

${ }^{2}$ This study does not aim at verifying causal relationships or showing which regions show higher or lower gender symmetry. These are relevant contributions, but to reach these types of results different research questions and hypotheses must be raised, and should be contextualized in an appropriate theoretical framework.
} 
Brazil is a country of continental size with accentuated differences in terms of socioeconomic development and ethnic composition. Its five administrative regions (Southeast, South, Northeast, North and Central-West) reflect these differences. The Brazilian urbanization rate ranges from $93 \%$ in the Southeast to $73 \%$ in the Northeast and the illiteracy rate varies from $17 \%$ in the Northeast to $5 \%$ in the South (IBGE, 2012). In addition, the Northeast and Northern regions are the poorest, where, according to 2008 data, between $24.9 \%$ and $17.6 \%$ of the population live in extreme poverty (IPEADATA, 2010).

It is a well-known fact that socioeconomic factors are related to family relations and outcomes (for a review of the international literature on the topic see CONGER, et al., 2010; for a discussion on regional differences in terms of family relations in Brazil, see SOUZA et al., 2001; SAMARA, 1997, 1987; CORRÊA, 1993; ALMEIDA, 1987). Consequently, the invariance of latent concepts across different Brazilian regions should be assured before these concepts can be reliably compared.

Concerns about measurement equivalence (invariance) are becoming evident in the methodological literature of the social sciences. The definition of invariance deals with similarities where latent concepts are interpreted among different cultures or cultural groups. Equivalence "implies that a concept can be meaningfully discussed in the cultures or cultural groups concerned" (BILLIET; WELKENHUYSEN-GYBELS, 2004, p.3). Consequently, it has been pointed out that comparisons between groups are unreliable without first assessing whether the concepts used are in fact equivalent (BILLIET, 2003; BILLIET; WELKENHUYSEN-GYBELS, 2004).

To my knowledge this is the first study to verify construct equivalence among the five Brazilian regions using DHS 2006 data. To this end, a step-by-step multi-group confirmatory factor analysis (MGCFA-BILLIET, 2003; DAVIDOV et al., 2011) will be applied in order to verify whether the concept of couples' joint decision-making can be meaningfully compared among the five Brazilian regions.

This study is structured into five sections, beginning with this present introduction. The second section situates gender relations inside Brazilian families, the third section briefly contextualizes the socioeconomic backgrounds and demographic differences of the five Brazilian regions. The fourth section presents the data and methods used, and the fifth presents the main results, which are then discussed in the sixth section.

\section{Gender relations in Brazilian families}

The classical view of gender relations in Brazilian families illustrates that the institutions of marriage and the family were historically constructed on the basis of hierarchical, authoritarian and patriarchal relationships, under strong influence from Catholic morality. Until the midtwentieth century family relations were defined by submission to the father/husband, his control over female sexuality and the concept of family honor. Control over female sexuality was intensified by ethnic and class differences. Historically men were "allowed" to have 
relationships with women from different social and ethnic groups, following different rational and moral codes (FREYRE, 2000 [1933]).

This model has been largely questioned and expanded. The patriarchal model described by Freyre serves as an excellent illustration of families from the higher social classes, mainly those of sugar cane owners in the Northeastern Region of Brazil during the colonial period (from the $16^{\text {th }}$ to the late $19^{\text {th }}$ centuries; SAMARA, 1987, 1997). However, many demographers and historians have argued that there was considerable variation in terms of family compositions and roles over different social strata and regions in the country (SOUZA et al., 2001; SAMARA, 1997, 1987; CORRÊA, 1993; ALMEIDA, 1987). It is now generally understood in Brazilian social sciences that the influence of the Catholic Church on family life, on the patriarchal model of family and gender, and on ethnic relations in families all vary considerably across Brazilian regions and social classes (SOUZA et al., 2001; SAMARA, 2002).

Historically, the patriarchal model of family has assumed different forms and intensities depending on the region and social or ethnic group under observation, and women's socioeconomic participation also varies considerably (SAMARA, 1997). Even in places where slavery was predominant (such as on the sugarcane plantations in the Northeast), the model of the patriarchal hierarchical family was not representative for the lower social classes. Although without social recognition or respect, women from these groups were consistently found to be participating in the social sphere and playing roles different than those described by the patriarchal model (SAMARA, 2002). This situation was intensified with the industrialization of the country during the second half of the $19^{\text {th }}$ century. Essentially, Brazilian industrialization continued, but with considerable participation of women, although in low-skilled positions (SAMARA, 2002).

Nowadays the patriarchal model of family is being questioned in both the public and the private spheres. In the public domain, legal protection has been given to women (ALVES; CORREA, 2009) and socioeconomic development is opening space for greater autonomy. Higher levels of education for women and participation in the labor force, as well as separation between their sexual and their reproductive lives (as a result of contraception), have favored a certain amount of individuation and independence. As stated above, Brazilian women have been attaining higher levels of formal education than men since the 1990s (BELTRÃO; ALVES, 2009; ESTEVE et al., 2012) and 43\% of them are participating in the labor market. In addition, the total fertility rate in Brazil has fallen from 6 to 1.9 births per woman in 50 years (IBGE, 2010).

These changes are expected to influence family relationships through more egalitarian processes. Some empowerment has been observed recently in terms of family formation (ITABORAÍ, 2010), as well as occupational, educational and age-related gaps between spouses and partners in all social classes (ITABORAÍ, 2012). Conversely, although some egalitarianism can be seen emerging in the upper social class and among couples with higher educational levels, men are still in charge of the general decision-making in Brazilian families (BRUSCHINI, 1989). 
Accordingly, there is much to be done in both the private and public spheres in order to further support development for women and promote gender equality. While the Brazilian state has shown positive progress in terms of public policies aiming at women's protection and empowerment since the Constitution of 1988 and the Cairo International Conference on Population and Development in 1994 (for detailed information see ALVES; CORREA, 2009), there is clearly room for public action toward improvements in work-family life (GOLDANI, 2002).

A large and growing body of literature has shown that, due to lack of public support (i.e. public day-care institutions, full-time schools, etc.), Brazilian women must take care of both professional duties and household work (GOLDANI, 2002). Montali (2004) illustrates the increased participation of women in the family income, but mentions that this contribution is still lower than their husbands'/partners' income and depends on the family composition. Soares (2008) compared the time invested by men and women in household work and concluded that women's participation in the workaday world does not reduce the time they spend on domestic tasks. Along the same vein, Sorj and colleagues (2007) claim that less support received from the state (i.e. in the form of day-care institutions and full-time schools) hinders the quantity and quality of women's (mainly mothers') participation in the job market.

This lack of public support combined with long-established gender values places Brazil in the context of having had an "incomplete gender revolution" (ESPING-ANDERSEN, 2009; MCDONALD, 2000). According to these authors, gender equity ${ }^{3}$ is distinguished in terms of individual- and family-level institutions. While the first part of the gender revolution is almost complete and has changed women's roles in individual-level institutions, such as education, the job market and public life, the second part of this revolution is taking place in family-oriented institutions at a much slower pace. Consequently, family organization and decision-making based on the patriarchal model still persists, even for two-income families (MCDONALD, 2000).

In addition, research on gender relations in Brazil to date has focused on describing trends rather than looking at correlations (or even at causal relationships) such as decisionmaking. This research gap indicates the importance of finding a construct that is able to measure gender relations in terms of decision-making, and increases the interest in research on couples' joint decision-making and the need for a reliable construct to measure it. Consequently, the first research question of this paper is: "Is it possible to extract the construct of 'joint decision' based on DHS questions?”

\section{Brazilian regions: socioeconomic evolution}

Brazil is a country with a unified language and geographical regions in different socioeconomic stages of development. ${ }^{4}$ Its expansive diversity implies the need to

\footnotetext{
${ }^{3}$ The gender equity model proposed by McDonald (2000) does not imply exact equality between women and men, but suggests that specific roles inside the family are not defined on the basis of gender (p.3).

${ }^{4}$ For a more detailed discussion on Brazilian economic development and its regional variations, see Furtado $(1999,2000)$, and Cano $(1985,1995)$.
} 
understand how couples' dynamics are embedded in these dissimilar environments. The contexts can be illustrated in terms of the five Brazilian regions, although attentive observers can note considerable variations in terms of socioeconomic development within each region as well.

In regard to regional differences, the anthropologist Darcy Ribeiro (1997) suggests that Brazil's vast territory $\left(8,547,403.5 \mathrm{~km}^{2}\right)$, its substantial and growing population (over 190 million in 2010) consisting of different cultures (mainly native indigenous, African and European heritages, but with participation of Asiatic, Arabian and other cultures as well), and its broad variety of climate, terrain and vegetation, have determined the division of Brazilian culture into different subcultures, ${ }^{5}$ distributed throughout the five regions (RIBEIRO, 1997).

According to 2011 data provided by IBGE (2013), the Northern and Northeastern Regions currently have the highest proportions of mixed-race populations (especially through a broad ethnic category described as pardos: mainly persons of native indigenous, European and African descent). In 2010, 68\% of the population of the North declared themselves pardos (or pardas), and $60 \%$ of those in the Northeast. The family model described by Freyre (2000 [1933]) as patriarchal and hierarchical, was most visible in the Northeast. According to Ribeiro (1997), both the Northern and the Northeastern subcultures are characterized by patriarchal social systems with emphasis on group norms and group loyalty (RIBEIRO, 1997).

Until the second half of the $19^{\text {th }}$ century, groups in the Southeastern and Southern Regions were formed by the union of Portuguese colonizers with indigenous persons and, in some cases, with African slaves. During the colonial period numerous groups embarked on expeditions far into the \Brazilian wilderness in search of areas for mining and with the intent to propagate the Brazilian population to the west of the Line of Demarcation (as determined in the Treaty of Tordesillas). During this period, while husbands went in groups into the wilderness, wives took care of the children and the household unit as a whole. This system fostered less hierarchical family relationships than those practiced in the North and Northeast (SOUZA et al., 2001; SAMARA, 1997, 1987; CORRÊA, 1993; ALMEIDA, 1987).

Today the descendants of these early settlers in the South and Southeast share their regions with social groups comprised of descendants from the large European immigrations of the $19^{\text {th }}$ and $20^{\text {th }}$ centuries, especially from Italy and Germany. These historical roots explain the contemporary majority of self-declared whites in the South and Southeast (78\% and $56 \%$, respectively - IBGE, 2013).

The last sub-culture identified by Ribeiro (1997) includes people from the interior of the Northeast and, particularly, of the Central-West, which present quite rural characteristics. The

\footnotetext{
${ }^{5}$ The concepts of Brazilian culture and regional subcultures defined by Ribeiro (1997) refer to the Brazilian culture as a homogeneous and integral part of a larger society within which regional subcultures interact in different ways than they would in relation to foreigners (p.254, author's translation).
} 
Central-Western Region contains the most balanced division of ethnicities in Brazil, with 43\% of whites, $48 \%$ of pardos, $7.6 \%$ of African descent and about $1 \%$ of persons with indigenous or Asiatic roots (IBGE, 2013). The development of this region began from the Atlantic Coast and was further accelerated when the country's administrative capital was moved from Rio de Janeiro to Brasília (Distrito Federal) in 1960. Although this region was relatively unsettled until that time, the establishment of a new city (Brasilia was built between 1956 and 1960) legitimated autonomy and differences in social status while the rural areas continued to have small populations devoted to subsistence (RIBEIRO, 1997).

The current socioeconomic development of Brazilian regions is related (among other factors) to different processes of occupation and industrialization. Industrialization and urbanization began earlier and happened faster in the southern parts of the country than those farther north (GUIMARÃES NETO, 1998; CANO, 1985, 1995). With the investments made in recent years, the gap in socioeconomic development among Brazilian regions has been reduced but is still evident (IBGE, 2012, p.168). The North and Northeast regions are the poorest and least developed in the country. There between $24.9 \%$ and $17.6 \%$ of the population were living in extreme poverty, comprising $11.6 \%, 6.9 \%$ and $5.5 \%$ of the populations in the Central-West, the Southeast and the South, respectively (IPEADATA, 2010). The North and Northeast also show the lowest Human Development Indexes, of 0.755 and $0.79 \%$, respectively, in contrast to $0.85 \%$ in the South and $0.84 \%$ in both the Southeast and the Central-West (BCB, 2009).

In demographic terms, there are also significant variations among Brazilian regions. Vasconcelos and Gomes (2012) showed that the demographic transition occurred at different paces and quanta in the five regions. According to these authors, while the Southeast, South and Central-West are in more advanced stages of the demographic transition, the North and Northeast show higher levels of fertility and mortality and have a younger age structure (VASCONSELOS; GOMES, 2012). In addition, Camarano and Carneiro (1998) concluded that a single pattern of family formation indicators (i.e. adolescent pregnancy, age at first childbirth, fertility control, among others) cannot be found across Brazilian regions.

This socioeconomic, demographic and cultural diversity raises concerns about how meaningful it would be to draw up comparisons among these regions in terms of latent concepts extracted from subjective survey questions such as couples' joint decision-making. This leads to the second research question of this study: "Is the latent variable of couples' joint decision-making equivalent among the five regions in Brazil?"

\section{Data and methods}

\section{Data}

As stated above, the Demographic and Health Survey (DHS) data from 2006 will be used. The DHSs are nationally representative surveys that collect comparable data on demographic and health issues in developing countries. The DHS provides insightful information on 
demographic and socio-economic characteristics at both household and individual levels. The samples are representative and focused on women at reproductive age (15-49 years old). The questionnaire includes several sections related to nuptiality, reproduction and health (BRASIL, 2009; CAVENAGHI, 2009). This present study is on the DHS's section on "Women's Status and Empowerment."

The section in the DHS on "Women's Status and Empowerment” includes the following questions: (i) Who usually makes decisions about making major household purchases (LSHOP)? (ii) Who usually makes decisions about making purchases for daily household needs (DSHOP)? (iii) Who usually makes decisions about visits to your family or relatives (VISIT)? (iv) Who usually makes decisions about what food should be cooked each day (FOOD)? and (v) Who usually makes decisions about the health care of your child(ren) (CHILD)? The alternatives are: Mainly you (the woman); Mainly your husband/partner; You and your husband/partner jointly; or Someone else.

The focus of this study is on couples' joint decision-makings. As a result, only women in a relationship (marriage or cohabitation), and who answered "Mainly you"; "Mainly your husband/partner"; or "You and your husband/partner jointly" were selected. The final sample was composed of 10,445 women. Following the recommendation of Cavenaghi (2009), information about sampling design (sampling with replacement) and sampling weights were used (CAVENAGHI, 2009 p. 28). Table 1 shows the distribution of the sample over the five Brazilian regions.

\section{TABLE 1}

Sample distribution by regions

Brazil-2006

\begin{tabular}{lc}
\hline \multicolumn{1}{c}{ Region } & N \\
\hline Central-West (CW) & 2,195 \\
North (N) & 1,721 \\
Northeast (NE) & 1,963 \\
South (S) & 2,357 \\
Southeast (SE) & 2,219 \\
\hline
\end{tabular}

Source: PNDS 2006 (http://bvsms.saude.gov.br/bvs/pnds).

After the sample was selected, the variables observed were re-coded into dichotomous variables. The value of zero (0) was given for non-joint answers of "Mainly you" and "Mainly your husband/partner"; and the value of one (1) was given to those who answered "You and your husband/partner jointly." ${ }^{6}$ Descriptive information on all observed variables are shown in the Appendix.

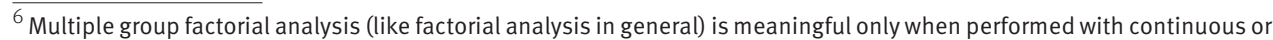
ordinal data (for more details about this approach, see the next section). Due to this constraint, the information on women's decisions or husbands'/partners' decisions could not be used in this analysis.
} 


\section{Method}

In order to verify whether the concept of couples' joint decision-making extracted from the DHS is equivalent across Brazilian regions, its measurement equivalence will be tested using multiple group confirmatory factor analysis (MGCFA) for ordered-categorical data. However, before dealing with MGCFA it is important to discuss how confirmatory factor analysis (CFA), as well as MGCFA itself, works with categorical data, in other words, in threshold models.

Threshold models are generally used to deal with linear models. In threshold models it is assumed that there is an unobserved continuous variable which underlies the ordinal variable. The probability distribution of this continuous variable is assumed to be responsible for the distribution of the observed ordinal variable. Thresholds make the "connection" between the unobserved continuous and the observed ordinal distribution. In this sense, each category of the ordinal variable represents an interval of the unobserved continuous variable. For an ordinal variable with $K$ categories, $K-1$ thresholds are calculated (BOLLEN, 1989). In the case of Brazilian gender equity, with dichotomous variables, only one threshold will be calculated.

Considering the dichotomous variables used in this study, it can be assumed that women in very egalitarian relationships make numerous decisions jointly with their husbands/partners, and answer (1) for the majority of the questions. But most of the women in non-egalitarian relationships, where the decisions are made mostly by themselves or their husbands/partners separately, will answer zero (0). These response categories are assumed to correspond to exhaustive, mutually exclusive and consecutive parts of an underlying continuous variable that the items are measuring (WELKENHUYSEN-GYBELS, 2003).

It is assumed that this underlying variable is distributed normally, the thresholds being estimated on the basis of data provided by the observed ordinal variable. Supposing that $30 \%$ of the respondents answered (1) for the first question Who usually makes decisions about making major household purchases? (BSHOP), threshold $\tau_{1}$ will be estimated in order to indicate which area of the normal curve this data represents: $\tau_{1}=\varphi^{-1}(0.30)$, where $\varphi^{-1}(0.30)$ denotes the inverse of the standard normal distribution, to which the z-value for the probability that a standard normal distribution is less or equal, given the proportion in the argument of the function.

Finally, the thresholds are used to calculate the Pearson product-moment correlation between two unobserved continuous variables that underlie two observed ordinal variables. Firstly, the thresholds are calculated based on a univariate marginal distribution of the observed ordinal variables and the polychoric correlation is then estimated from the bivariate marginal distribution. This reasoning allows for the minimization of the difference between the observed frequencies and the expected frequencies of the thresholds. Figure 1 illustrates the path diagram of the confirmatory factor analysis (CFA) tested in this study. 
FIGURE 1

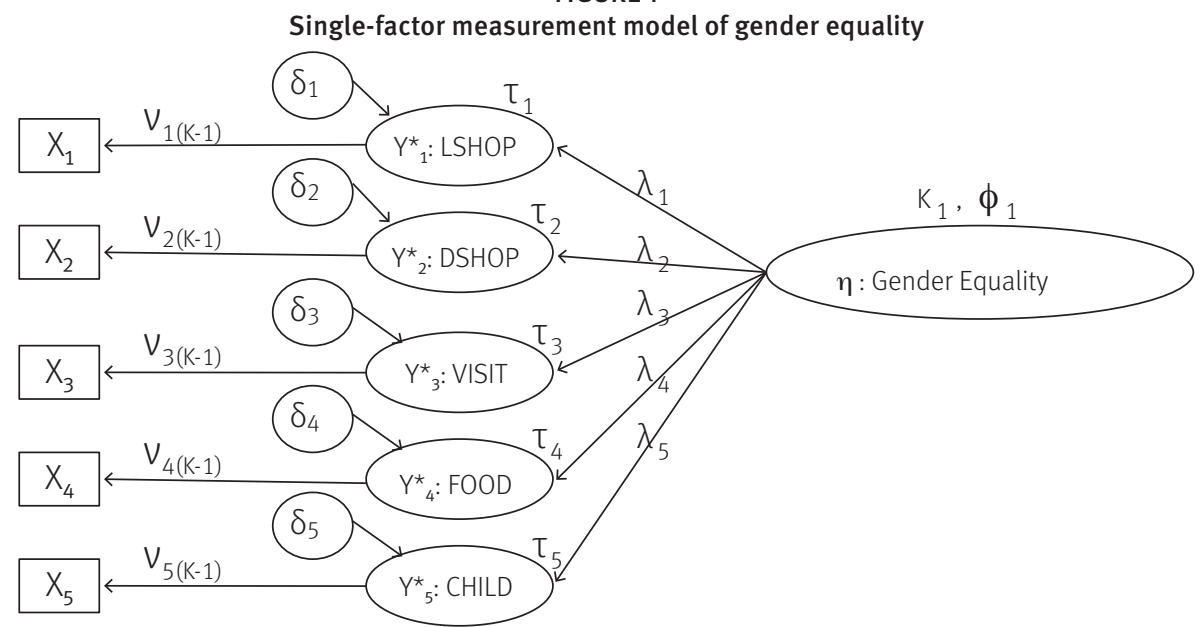

Source: Based on the model proposed by Davidov et al. (2011, p. 160).

Note: $\mathrm{LSHOP}=$ decision-making on household purchases; VISIT= visits to family or relatives; FOOD=what food should be cooked each day; CHILD= child's health care decisions; DSHOP= making purchases for daily household needs.

Confirmatory factor analyses for ordinal data assume that the observed variables (X's) are indirectly influenced by their corresponding latent factor ( $\mathrm{n}$ : gender quality) via a continuous latent response variable $\left(\mathrm{Y}^{\star}\right)$. Consequently, the item-specific threshold parameters $(v)$ must be specified. The threshold parameters divides the "continuous normally distributed latent response variable into several categories” (K) (DAVIDOV et al., 2011, p. 159), and $k-1$ thresholds are calculated. The factor loadings $(\lambda)$ and the intercepts $(\tau)$ are calculated in the same way as in continuous CFA (DAVIDOV et al., 2011).

The next topic is about MGCFA tests for configural, metric and scalar invariance. Configural invariance specifies that "the same indicators measure the same theoretical constructs across groups" (DAVIDOV et al., 2011, p. 150). Scalar invariance attests whether the intercepts of each item are the same across groups and allow for comparisons of mean latent variables. "The scalar invariance model constrains the means of the latent variables to zero in one group (referred to as the reference group) and estimates them in the other groups" (DAVIDOV et al., 2011, p. 150). Finally, metric invariance indicates that the respondent interprets the scale used in the same way.

The distinction of metric invariance for ordinal data is not meaningful. This is because "the probability curves item (i.e., the scores of the ordinal indicators) are jointly influenced by the factor loadings ( $\lambda$ 's), the intercepts ( $\tau$ 's), and the thresholds (v's)" (DAVIDOV et al., 2011, p. 160). In order to distinguish metric and scalar invariance in the ordinal case it would be necessary to constrain the factor loadings ( $\lambda$ 's), the intercepts ( $\tau$ 's), and the thresholds ( $v$ 's) simultaneously (DAVIDOV et al., 2011), which will not guarantee that the response curves have the same slope. 
The measurement equivalence of the gender equality construct was tested by fitting a sequence of MGCFA models for ordered-categorical data. ${ }^{7}$ As stated before, in these models, the five dichotomous variables observed serve as indirect indicators of the latent gender equality variable, functioning via respective underlined continuous variables. Firstly singlegroup models for the five regions were fit separately (BYRNE, 2001), followed by the same model for the cumulative sample with all regions together. Secondly, five nested MGCFA models were estimated, one for each region.

In order to test whether the construct of gender equality is equivalent among the five Brazilian regions the following models were applied. First, a configural equivalence model was estimated, in which factor loadings and thresholds were allowed to vary over groups. Secondly, a full equivalence model was tested. In this model the factor loadings and thresholds were constrained to be equal over Brazilian regions. If full scalar invariance cannot be attested, a final partial scalar model will be fit. According to Byrne, et al. (1989) full scalar equivalence is not a necessary condition for comparisons to be valid. If at least two indicators of the latent variable are equivalent, comparisons can be reliably made across regions (BYRNE et al., 1989). In this sense, if the full scalar model does not fit the data, a partial scalar model will. In this model, the factor loadings and intercepts of some indicators will be constrained to be free in order to obtain a better model fit and ensure no sizeable cross-group differences.

Considering the size of the sample, chi-square statistics will not be used to evaluate the fit of the models. Instead, the fit of the models will be assessed on the basis of global and local fit indices, as well as by looking at differences between the models in terms of the root mean square error of approximation (RMSEA) and the comparative fit index (CFI) (MARSH et al., 2004). According to Marsh et al. (2004) a minimum value of 0.90-0.95 for the CFI and a maximum value of 0.05-0.08 for the RMSEA indicate an acceptable fit of a model.

\section{Results}

\section{Single-group analysis}

Table 2 presents the goodness-of-fit statistics for each region and for the complete Brazilian sample. As expected, all of the chi-square statistics were highly significant (not shown), which, in structural equation models, means that the model does not fit the data. However, it is well known that the chi-square statistic is very sensitive to sample size and, for this reason, it was not considered in the analysis.

\footnotetext{
${ }^{7}$ The software programs for structural equation model in LISREL (JÖRESKOG; SÖRBOM, 1996) and MPlus (MUTHÉN; MUTHÉN, 2007) identify models fitted to ordinal data in different ways. While LISREL assumes that that the thresholds are equal across groups, MPlus allows for testing whether this is true (DAVIDOV et al., 2011). Based on this difference, MPlus was used. The syntaxes are available to the scientific community upon request.
} 
TABLE 2

Summary of single-group analysis and complete samples by regions

Brazil - 2006

\begin{tabular}{|c|c|c|c|c|c|c|c|c|c|}
\hline \multirow{2}{*}{ Region } & \multicolumn{5}{|c|}{ Standardized factor loadings $(\lambda)$} & \multirow{2}{*}{$\mathrm{N}$} & \multirow{2}{*}{$\mathrm{CFI}$} & \multirow{2}{*}{ TLI } & \multirow{2}{*}{ RMSEA } \\
\hline & LSHOP & VISIT & FOOD & CHILD & DSHOP & & & & \\
\hline Central-West (CW) & $\begin{array}{c}0.946 \\
(0.009)\end{array}$ & $\begin{array}{c}0.981 \\
(0.005)\end{array}$ & $\begin{array}{c}0.610 \\
(0.033)\end{array}$ & $\begin{array}{c}0.725 \\
(0.023)\end{array}$ & $\begin{array}{c}0.981 \\
(0.005)\end{array}$ & 2.195 & 0.999 & 0.999 & 0.036 \\
\hline North (N) & $\begin{array}{c}0.959 \\
(0.008)\end{array}$ & $\begin{array}{c}0.994 \\
(0.005)\end{array}$ & $\begin{array}{l}0.630 \\
(0.031) \\
\end{array}$ & $\begin{array}{c}0.740 \\
(0.024)\end{array}$ & $\begin{array}{c}0.994 \\
(0.005)\end{array}$ & 1.721 & 1.000 & 1.000 & 0.000 \\
\hline Northeast (NE) & $\begin{array}{c}0.915 \\
(0.011) \\
\end{array}$ & $\begin{array}{c}0.993 \\
(0.005)\end{array}$ & $\begin{array}{c}0.664 \\
(0.034)\end{array}$ & $\begin{array}{c}0.684 \\
(0.027) \\
\end{array}$ & $\begin{array}{c}0.993 \\
(0.005)\end{array}$ & 1.963 & 1.000 & 1.000 & 0.016 \\
\hline South (S) & $\begin{array}{c}0.866 \\
(0.014) \\
\end{array}$ & $\begin{array}{c}0.981 \\
(0.006)\end{array}$ & $\begin{array}{c}0.689 \\
(0.025)\end{array}$ & $\begin{array}{c}0.738 \\
(0.022)\end{array}$ & $\begin{array}{c}0.981 \\
(0.006)\end{array}$ & 2.357 & 0.998 & 0.997 & 0.035 \\
\hline Southeast (SE) & $\begin{array}{l}0.908 \\
(0.011) \\
\end{array}$ & $\begin{array}{c}0.994 \\
(0.005)\end{array}$ & $\begin{array}{c}0.628 \\
(0.029)\end{array}$ & $\begin{array}{c}0.700 \\
(0.024)\end{array}$ & $\begin{array}{c}0.994 \\
(0.005)\end{array}$ & 2.219 & 1.000 & 1.000 & 0.000 \\
\hline Complete Sample & $\begin{array}{c}0.921 \\
(0.005)\end{array}$ & $\begin{array}{c}0.986 \\
(0.003)\end{array}$ & $\begin{array}{c}0.647 \\
(0.013)\end{array}$ & $\begin{array}{c}0.720 \\
(0.011)\end{array}$ & $\begin{array}{c}0.986 \\
(0.003)\end{array}$ & 10.455 & 0.999 & 0.999 & 0.024 \\
\hline
\end{tabular}

Source: PNDS 2006 (http://bvsms.saude.gov.br/bvs/pnds).

Note: Standard errors between brackets. LSHOP=decision-making on household purchases; VISIT= visits to family or relatives; FOOD=what food should be cooked each day; CHILD= child's health care decisions; DSHOP= making purchases for daily household needs.

The global fit of the six models is very good. CFI and TLI exceeded the threshold of 0.95 in all samples and the RMSEA was lower than 0.04 in all cases. In addition, all factor loadings are sufficiently high, indicating that the items are measuring the same concept. This indicates that the five items are valid and reliable indicators of the construct of gender equality. These outcomes indicate that a multi-group analysis is meaningful.

\section{MGCFA testing for measurement equivalence}

Table 3 shows the goodness-of-fit of the MGCFA models. The configural equivalence model was used as a baseline model, in which the goodness of fit will be compared to the more restricted models (VANDENBERG; LANCE, 2000). In the configural equivalence model, the five indicators of gender equality load on the latent construct in all five Brazilian regions with no equality constraints imposed on factor loadings or thresholds. This model fits the data very well with $\mathrm{CFI}=0.999$ and $\mathrm{RMSEA}=0.04$. This means that the measurement model for gender equality has a very similar factor structure across groups. In other words, an indicator that loads strongly on the latent factor in one group also loads strongly in other groups (STEENKAMP; BAUMGARTNER, 1998). Consequently, up to this point it is possible to say that gender equity can be meaningfully discussed in all Brazilian regions.

TABLE 3

MGCFA models - Goodness-of fit

\begin{tabular}{lcccccc}
\hline \multicolumn{1}{c}{ Model } & X2 & DF & p-value & CFI & TLI & RMSEA \\
\hline 1. Configural equivalence & 86380 & 25 & 0.0000 & 0.999 & 0.998 & 0.040 \\
2. Full scalar equivalence & 168435 & 37 & 0.0000 & 0.998 & 0.997 & 0.048 \\
3. Partial scalar equivalence & 102889 & 32 & 0.0000 & 0.999 & 0.998 & 0.038 \\
\hline
\end{tabular}

Source: PNDS 2006 (http://bvsms.saude.gov.br/bvs/pnds).

Note: Models fit independently for each region, but run together. The goodness-of-fit shows the overall fit of each of the three tested models. 
Next, the full scalar equivalence model was fit. In the full scalar equivalence model both the factor loadings and the thresholds were restricted to be equal across regions. The global fit of this model was acceptable, but worse than those observed in the baseline (configural) model: $C F I=0.998$ and RMSEA=0.048. The goodness-of-fit of the model is still very good. However, it is clearly worse than the configural model, which does not guarantee construct equivalence. But, as stated above, a full scalar equivalence is not a compulsory condition for comparisons to be valid, and when at least two indicators of the latent construct are equivalent, comparisons can be reliably made across regions (BYRNE et al., 1989).

Following the advice of Byrne et al. (1989), the partial scalar equivalence was tested. Looking at the modification indices (MIs) and at the expected parameter changes (EPCS), sources of misfit in the full scalar model could be located. Based on the MIs and EPCs, the indicators of decision-making about the food to be cooked daily (FOOD); when to visit relatives (VISIT); and decisions about the health of children (CHILD) for the Southeastern region seem to have the most problematic equality constraints. Consequently, their threshold parameters were set to be free in a partially scalar model (Model 3, Table 3).

The goodness-of-fit of the partial scalar model is very good and even better than that of the baseline configural model. In comparison to the configural model (1), the partial scalar model (3) presents the same CFIs and TLIs (0.999 and 0.998) and a lower RMSEA (0.038). This indicates that there are no longer any sizable cross-sample differences in factor loadings or thresholds and attests that the gender equality construct can be meaningfully compared among the five Brazilian regions.

The assessment of measurement equivalence is not only important for attesting construct comparability. The deviations from the full equivalence can provide valuable information about the differences across regions (POORTINGA, 1989). This information can be easily visualized by plotting the pattern of responses (thresholds) in the partial scalar model across the five Brazilian regions in comparison to latent mean scores of the gender equality variable. This plot is shown in Graph 1.

GRAPH 1

Pattern of responses to the DHS 2006 for gender equality indicators Brazil - 2006

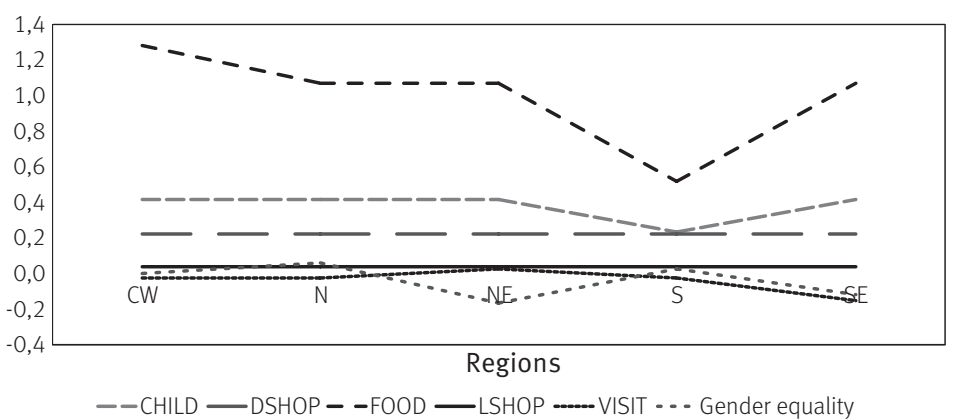

Source: PNDS 2006 (http://bvsms.saude.gov.br/bvs/pnds).

Note: LSHOP=decision-making on household purchases; VISIT= visits to family or relatives; FOOD=what food should be cooked each day; CHILD= child's health care decisions; DSHOP= making purchases for daily household needs. 
Graph 1 shows that the patterns of answers are fairly comparable among the five Brazilian regions. The only exception is the threshold for the indicator FOOD, which seems to differ considerably between the Southern Region and the others. This confirms the conclusion that the construct of gender equality can be meaningfully compared across the country.

As stated above, this study does not aim at showing which regions show higher or lower gender symmetry. For such a research point, questions and hypothesis should be raised, which should then be contextualized in an appropriate theoretical framework. However, it seems meaningful to look at the mean scores (MS) of the construct of couple's joint decisionmaking for each of the regions in Brazil, in a descriptive way, in order to discern in which regions couples are more or less likely to make decisions jointly. It was found that couples are more likely to make joint decisions in the North (MS=0. 10), followed by the Central-West (MS=0.04), then the South (MS=0.02), the Southeast $(M S=-0.01)$ and, finally, the Northeast (MS=-0.14), which is the region where couples are the least likely to make joint decisions.

\section{Conclusion}

A good number of studies have been published that describe changes in women's position in Brazilian society. Results point to the existence of the so-called "incomplete revolution", where many improvements can be seen in the roles of women in public institutions (i.e. education, participation in the job market, etc.), but very few are noted in private spheres, such as the family (ESPING-ANDERSEN, 2009; MCDONALD, 2000). So far, however, there has been little discussion about the impact of changing roles of women on gender relations in terms of decision-making in Brazilian families. This dearth is probably due to the absence of comparable broad-scale surveys on the topic.

This study uses questions from the Brazilian DHS given in 2006 to measure the construct of gender relations in terms of couples' joint decision-making, as well as its measurement equivalence across the five Brazilian regions. The results show that the DHS items can be reliably used for measuring gender equality and that this construct can be meaningfully compared among the five Brazilian regions. It was also found that the likelihood of a couple to make joint decisions differs from one region to another. Considering the above mentioned socioeconomic differences found over these regions, and that socioeconomic indicators such as industrialization, urbanization and ethnic composition are known to influence family life, the differences found call for further investigation.

A number of caveats must be addressed regarding the present study. First, and probably the most important, is the focus of the analysis on couples' joint decision-makings. The method used does not allow for the evaluation of a power balance in terms of decision-making between women and men, but only for assessment of the level of the joint decisions inside these families. Another important limitation is related to the concept of type of family employed in the survey. Recent data provided by IBGE (2012) shows that heterosexual couples (with or without children) represent only 64.8 percent of the total of Brazilian families. 
These findings contribute to the demographic and sociological research on gender relations which can use this construct and other indicators provided by the DHS to identify the causal processes related to the construct in further studies, as well as the main regional differences. In addition, further research is encouraged to disentangle these causal processes as well as to verify whether the construct of gender equality can be meaningfully compared among other developing countries covered by the DHS.

\section{References}

ALMEIDA, A. M. Notas sobre a família no Brasil. In: ALMEIDA, A. M. et al. (Orgs.). Pensando a família no Brasil: da colônia à modernidade. Rio de Janeiro: Espaço e Tempo, Editora da UFRRJ, 1987.

ALVES, J. E. D.; CORREA, S. Igualdade e desigualdade de gênero no Brasil: um panorama preliminar, 15 anos depois do Cairo. Brasil, 15 anos após a Conferência do Cairo. Campinas: Abep, 2009, 121-223.

BELTRÃO, K. I.; ALVES, J. E. D. A reversão do hiato de gênero na educação brasileira no século XX. Cadernos de Pesquisa, v. 39, n. 136, p. 125-156, 2009.

BCB - Banco Central do Brasil. Evolução do IDH das Grandes Regiões e Unidades da Federação. Boletim Regional do Banco Central do Brasil, Janeiro 2009.

BILLIET, J. Cross-cultural equivalence with structural equation modeling. In: VAN DE VIJVER, F. J. R.; MOHLER, P. P. (Eds.). Cross-cultural survey methods. Hoboken, NJ: John Wiley \& Sons, 2003.

BILLIET, J.; WELKENHUYSEN-GYBELS, J. Assessing cross-national construct equivalence in the ESS: the case of six immigration items. In: VAN DIJKUM, C.; BLASIUS, J.; DURAND, C. (Eds.). Recent developments and applications in social research methodology. Amsterdam: Barbara Budrich Pub. Proceedings of the Sixth International Conference on Social Science Methodology, August 17-20 2004.

BOLLEN, K. Structural equations with latent variables. Wiley, 1989.

BRASIL. Ministério da Saúde. Pesquisa Nacional de Demografia e Saúde da Criança e da MulherPNDS 2006: dimensões do processo reprodutivo e da saúde da criança. 2009.

BRUSCHINI, M. C. Uma abordagem sociológica da família. Revista Brasileira de Estudos de População, v. 6, n. 1, p. 1-24, 1989.

BYRNE, B. M.; SHAVELSON, R. J.; MUTHÉN, B. Testing for the equivalence of factor covariance and mean structures: the issue of partial measurement invariance. Psychological Bulletin, n. 105, p. 456-466, 1989.

BYRNE, B. M. Structural equation modeling with AMOS: basic concepts, applications, and programming. Mahwah, NJ: Lawrence Erlbaum Associates, Inc, 2001.

CAMARANO, A. A.; CARNEIRO, I. G. Padrões de formação de família por regiões brasileiras e grupos sociais: diferenças ou semelhanças? In: XI ENCONTRO NACIONAL DE ESTUDOS POPULACIONAIS. Anais... Caxambu: Abep, 1998.

CANO, W. Desequilíbrios regionais e concentração industrial no Brasil. São Paulo: Global, 1985.

. Auge e inflexão da desconcentração econômica regional. In: AFFONSO, R. B. A.; SILVA, P. L. B. A federação em perspectiva. São Paulo: Fundap, 1995.

CAVENAGHI, S. M. Aspectos metodológicos e comparabilidade com pesquisas anteriores. In: BRASIL. Ministério da Saúde. Pesquisa Nacional de Demografia e Saúde da Criança e da Mulher - PNDS 2006: dimensões do processo reprodutivo e da saúde da criança. Brasília: Ministério da Saúde, Centro Brasileiro de Análise e Planejamento, 2009, v. 1, p. 13-32 (Série G. Estatística e Informação em Saúde). 
CONGER, R. D.; CONGER, K. J.; MARTIN, M. J. Socioeconomic status, family processes, and individual development. Journal of Marriage and the Family, v. 72, n. 3, p. 685-704, 2010.

CORRÊA, M. Repensando a família patriarcal brasileira: notas para o estudo das formas de organização familiar no Brasil. In: CORRÊA, M. (Org.). Colcha de retalhos: estudos sobre a família no Brasil. 2. ed. Campinas: Editora da Unicamp, 1993.

DAVIDOV, E.; DATLER, G.; SCHMIDT, P.; SCHWARTZ, S. H. Testing the invariance of values in the Benelux countries with the European Social Survey: accounting for ordinality. Cross-cultural analysis: methods and applications. European out ledge, 2011, p. 149-168.

ENGUITA, M. F. Os desiguais resultados das políticas igualitárias: classe, gênero e etnia na educação. Revista Brasileira de Educação, n. 3, p. 5-17, set./dez. 1996.

ESPING-ANDERSEN, G. The incomplete revolution: adapting to women's new roles. Cambridge: Polity Press, 2009.

ESTEVE, A.; GARCÍA-ROMÁN, J.; PERMANYER, I. The gender-gap reversal in education and its effect on union formation: the end of hypergamy? Population and Development Review, v. 38, n. 3 , p. 535-546, 2012.

FREYRE, G. Casa grande e senzala: formação da família brasileira sob o regime de economia patriarcal. 41st ed. Rio de Janeiro: Record, 2000 (1933).

FURTADO, C. O longo amanhecer: reflexões sobre a formação do Brasil. São Paulo: Editora Paz e Terra, 1999.

. Em busca de um novo modelo: reflexões sobre a crise contemporânea. São Paulo: Editora Paz e Terra, 2002.

GOLDANI, A. M. Família, gênero e políticas: famílias brasileiras nos anos 90 e seus desafios como fator de proteção. Revista Brasileira de Estudos de População, v. 19, n. 1, 2002.

GUEDES, M. O contingente feminino de nível universitário nos últimos trinta anos do século XX: a reversão de um quadro desigual. In: XIV ENCONTRO NACIONAL DE ESTUDO POPULACIONAL. Anais... Caxambu: Abep, 2004, p. 1-17.

GUIMARÃES NETO, L. Ciclos econômicos e desigualdades regionais no Brasil. Caderno de Estudos Sociais, v. 14, n. 2, p. 315-342, jul./dez. 1998.

IBGE - Instituto Brasileiro de Geografia e Estatística. Síntese de indicadores sociais: uma análise das condições de vida da população brasileira 2012. Estudos e Pesquisas. Informação demográfica e socioeconômica, n. 29, 2012.

Banco de Dados Agregados. Sistema IBGE de Recuperação Automática -SIDRA. Disponível em: 〈http://www.ibge.gov.br〉. Acesso em: 15 abr. 2013.

Rio de Janeiro, 2010

Censo Demográfico 2010. Nupcialidade, fecundidade e migração: resultados da amostra.

IPEA. Dimensão, evolução e projeção da pobreza por região e por estado no Brasil. Comunicados do Ipea, n. 58, 2010.

ITABORAÍ, N. R. A nupcialidade brasileira do ponto de vista das relações de gênero e classe. In: IV CONGRESSO DA ASSOCIAÇÃO LATINO AMERICANA DE POPULAÇÃO. Anais... Havana: Alap, 2010.

. Um novo equilíbrio de poder? Mudanças na composição dos casais nas famílias brasileiras 1976-2006. In: V CONGRESSO DA ASSOCIAÇÃO LATINO AMERICANA DE POPULAÇÃO. Anais... Montevidéu: Alap, 2012.

LESTHAEGHE, R. J.; SURKYN, J. Cultural dynamics and economic theories of fertility change. Population 
and Development Review, v. 14, n. 1, p. 1-45, 1988.

MARSH, H. W.; HAU, K.; WEN, Z. In search of golden rules: comment on hypothesis-testing approaches to setting cutoff values for fit indexes and dangers in over generalizing Hu and Bentler's (1999) findings. Structural Equation Modeling, n. 11, p. 320-341, 2004.

MCDONALD, P. Gender equity, social institutions and the future of fertility. Journal of Population Research, v. 17, n. 1, p. 1-16, 2000.

MONTALI, L. Rearranjos familiares de inserção, precarização do trabalho e empobrecimento. In: XIV ENCONTRO NACIONAL DE ESTUDOS POPULACIONAIS. Anais... Caxambu: Abep, 2004.

POORTINGA, Y. H. Equivalence of cross-cultural data: an overview of basic issues. International Journal of Psychology, v. 24, n. 1, p. 737-756, 1989.

RIBEIRO, D. O povo brasileiro: a formação e sentido do Brasil. São Paulo: Companhia das Letras, 1997. RODRÍGUEZ-VIGNOLI, J. R. Unión y cohabitación en América Latina: ¿modernidad, exclusión, diversidad? Cepal - Serie Población y desarrollo, n. 57, p. 1-65, 2005.

ROSEMBERG, F. Políticas educacionais e gênero: um balanço dos anos 1990. Cadernos Pagu, n. 16, p. 151-197, 2002.

Educação formal, mulher e gênero no Brasil contemporâneo. Estudos Feministas, n. 2, p. 515-540, 2001.

RUTSTEIN, S. O.; ROJAS, G. Guide to DHS Statistics. Demographic and Health Surveys. Calverton, Maryland: ORC Macro, 2006.

SAMARA, E. M. O que mudou na família brasileira? (Da Colônia à atualidade). Psicologia USP, v. 13, n. 2, 2002.

. A família no Brasil: história e historiografia. História Revista, v. II, n. 2, p. 7-21, jul./dez. 1997.

. Tendências atuais da história da família no Brasil. In: ALMEIDA, A. M. et al. (Orgs.). Pensando a família no Brasil: da colônia à modernidade. Rio de Janeiro: Espaço e Tempo, Editora da UFRRJ, 1987.

SOARES. C. A distribuição do tempo dedicado aos afazeres domésticos entre homens e mulheres no âmbito da família. In: XVI ENCONTRO NACIONAL DE ESTUDOS POPULACIONAIS. Anais... Caxambu: Abep, 2008.

SORJ, B.; FONTES, A.; MACHADO, D. C. Políticas e práticas de conciliação entre família e trabalho no Brasil. Cadernos de Pesquisa, v. 37, n. 132, p. 573-594, set./dez. 2007.

SOUZA, C. V.; BOTELHO, T. R. Modelos nacionais e regionais de família no pensamento social brasileiro. Rev. Estud. Fem., v. 9, n. 2, 2001.

STEENKAMP, J. E.; BAUMGARTNER, H. Assessing measurement invariance in cross-national consumer research. Journal of Consumer Research, n. 25, p. 78-90, 1998.

VANDENBERG, R. J.; LANCE, C. E. A review and synthesis of the measurement invariance literature: suggestions, practices, and recommendations for organizational research. Organizational Research Methods, n. 3, p. 4-70, 2000.

VASCONCELOS, A. M. N.; GOMES, M. M. F. Transição demográfica: a experiência brasileira. Epidemiol. Serv. Saúde, v. 21, n. 4, dez. 2012.

WELKENHUYSEN-GYBELS, J. The detection of differential item functioning in Likert score items. Leuven: Department Sociologie, 2003.

WORLD BANK. Gender Statistics. Washington, D.C.: The World Bank, 2010. 


\section{Author}

Maira Covre-Sussai is a PhD candidate in Social Science at University of Leuven, Leuven, Belgium and has a master degree in Quantitative Analysis in Social Science.

\section{Correspondence address}

Maira Covre-Sussai

Parkstraat 45 / box 3601

3000 Leuven, Belgium

\section{Resumo}

Tomada de decisão conjunta: construção e validação de uma proxy-chave para o estudo das relações de gênero de casais contemporâneos

Relações de gênero tornou-se um construto fundamental para os estudos da família. A compreensão das relações de gênero como determinante e resultado de novas configurações familiares requer a utilização de levantamentos específicos visando a dinâmica dos casais. Infelizmente, pesquisas nacionais representativas deste tipo não estão disponíveis para países latino-americanos. No entanto, dados da Pesquisa Nacional de Demografia e Saúde - PNDS 2006 incluem informações sobre tomadas de decisões, que podem servir de construto para mensuração da igualdade de gênero. Este estudo tem como objetivo avaliar se o construto relações de gênero, referindo-se à tomada de decisão conjunta pelos casais, pode ser extraído da PNDS 2006 e se o mesmo é comparável nas cinco regiões brasileiras. Para este fim, uma análise fatorial confirmatória para multigrupos (MGCFA) foi aplicada. Os resultados mostram que os itens da PNDS 2006 medem o mesmo conceito e podem ser significativamente comparados entre as regiões brasileiras. Estes resultados contribuirão para futuras investigações demográficas e sociológicas acerca das relações de gênero, que podem usar este conceito para identificar os processos causais relacionados ao mesmo.

Palavras-chave: Relações de gênero. Tomada de decisão. Análise fatorial confirmatória para multigrupos (MGCFA). Equivalência de mensuração.

\section{Resumen}

Decisiones conjuntas de las parejas: la construcción y validación de los elementos fundamentales para entender las relaciones de género en familias contemporáneas

Las relaciones de género se convirtieron en una dimensión fundamental de los estudios familiares. Su entendimiento como un factor determinante y resultante de nuevas configuraciones familiares exige encuestas específicas sobre la dinámica de las parejas. Desafortunadamente, encuestas nacionales representativas sobre el tema no se encuentran disponibles en los países latinoamericanos. Sin embargo, las últimas fases de las Encuestas de Demografía y Salud - Demographic and Health Surveys (DHS) incluyen una sección denominada 'Status y Empoderamiento de las Mujeres', que también puede suministrar informaciones sobre cuestiones de género. Este artículo tiene el propósito de evaluar la construcción de relaciones de género en lo concerniente a las decisiones conjuntas de la pareja en cinco regiones de Brasil. Para ello, se efectuó un análisis factorial confirmatorio paso a paso entre múltiples grupos (MGCFA) para verificar si dicho concepto puede utilizarse para efectuar comparaciones entre las regiones brasileñas. Los resultados muestran que las DHS pueden ser utilizadas de forma confiable para medir las decisiones conjuntas de las parejas y que ello se puede comparar con otras regiones. Estos 
hallazgos contribuirán para investigaciones demográficas y sociológicas sobre relaciones de género que podrán utilizar este concepto y otros indicadores proporcionados por las DHS para identificar los procesos causales relacionados a ellos.

Palabras-claves: Relaciones de género. Decisiones conjuntas. Análisis factorial confirmatorio de múltiples grupos. Medición de invariancia.

\section{Appendix}

\section{Descriptive values (1) of observed selected variables by region Brazil - 2006}

CHILD: Who decides about the health of your child?

\begin{tabular}{llcrr}
\hline & & Individual decision & Joint decision & Total \\
\hline \multirow{3}{*}{ Central-West } & Count & 1,034 & 541 & 1,575 \\
& \% within Central-West & 65.7 & 34.3 & 100.0 \\
& \% within Brazil & 19.4 & 21.7 & 20.1 \\
\hline \multirow{3}{*}{ North } & Count & 831 & 474 & 1,305 \\
& \% within North & 63.7 & 36.3 & 100.0 \\
& \% within Brazil & 15.6 & 19.0 & 16.7 \\
\multirow{3}{*}{ Northeast } & Count & 1,128 & 386 & 1,514 \\
& \% within Northeast & 74.5 & 25.5 & 100.0 \\
\hline \multirow{3}{*}{ South } & \% within Brazil & 21.1 & 15.5 & 1,777 \\
& Count & 1195 & 582 & 100.0 \\
\hline \multirow{3}{*}{ Southeast } & \% within South & 67.2 & 32.8 & 22.7 \\
& \% within Brazil & 22.4 & 23.3 & 1,665 \\
& Count & 1,153 & 512 & 100.0 \\
\multirow{2}{*}{ Brazil } & \% within Southeast & 69.2 & 30.8 & 21.2 \\
& Count & 21.6 & 20.5 & 7,836 \\
& & 5,341 & 2,495 & 100.0 \\
\hline
\end{tabular}

continue...

LSHOP: Who decides about large household shopping?

\begin{tabular}{|c|c|c|c|c|}
\hline & & Individual decision & Joint decision & Total \\
\hline \multirow{3}{*}{ Central-West } & Count & 1,173 & 1,006 & 2,179 \\
\hline & $\%$ within Central-West & 53.8 & 46.2 & 100.0 \\
\hline & \% within Brazil & 20.8 & 21.2 & 21.0 \\
\hline \multirow{3}{*}{ North } & Count & 872 & 838 & 1,710 \\
\hline & $\%$ within North & 51.0 & 49.0 & 100.0 \\
\hline & $\%$ within Brazil & 15.5 & 17.7 & 16.5 \\
\hline \multirow{3}{*}{ Northeast } & Count & 1,170 & 775 & 1,945 \\
\hline & $\%$ within Northeast & 60.2 & 39.8 & 100.0 \\
\hline & $\%$ within Brazil & 20.8 & 16.4 & 18.8 \\
\hline \multirow{3}{*}{ South } & Count & 1,160 & 1,180 & 2,340 \\
\hline & $\%$ within South & 49.6 & 50.4 & 100.0 \\
\hline & $\%$ within Brazil & 20.6 & 24.9 & 22.6 \\
\hline \multirow{3}{*}{ Southeast } & Count & 1,260 & 936 & 2,196 \\
\hline & $\%$ within Southeast & 57.4 & 42.6 & 100.0 \\
\hline & $\%$ within Brazil & 22.4 & 19.8 & 21.2 \\
\hline \multirow{2}{*}{ Brazil } & Count & 5,635 & 4,735 & 10,370 \\
\hline & $\%$ & 54.3 & 45.7 & 100.0 \\
\hline
\end{tabular}


DSHOP: Who decides about daily household shopping?

\begin{tabular}{|c|c|c|c|c|}
\hline & & Individual decision & Joint decision & Total \\
\hline \multirow{3}{*}{ Central-West } & Count & 1,332 & 851 & 2,183 \\
\hline & $\%$ within Central-West & 61.0 & 39.0 & 100.0 \\
\hline & $\%$ within Brazil & 20.3 & 22.1 & 21.0 \\
\hline \multirow{3}{*}{ North } & Count & 959 & 758 & 1,717 \\
\hline & $\%$ within North & 55.9 & 44.1 & 100.0 \\
\hline & $\%$ within Brazil & 14.6 & 19.7 & 16.5 \\
\hline \multirow{3}{*}{ Northeast } & Count & 1,334 & 618 & 1,952 \\
\hline & $\%$ within Northeast & 68.3 & 31.7 & 100.0 \\
\hline & \% within Brazil & 20.3 & 16.1 & 18.8 \\
\hline \multirow{3}{*}{ South } & Count & 1,506 & 842 & 2,348 \\
\hline & $\%$ within South & 64.1 & 35.9 & 100.0 \\
\hline & $\%$ within Brazil & 23.0 & 21.9 & 22.6 \\
\hline \multirow{3}{*}{ Southeast } & Count & 1,426 & 775 & 2,201 \\
\hline & $\%$ within Southeast & 64.8 & 35.2 & 100.0 \\
\hline & $\%$ within Brazil & 21.7 & 20.2 & 21.2 \\
\hline \multirow{2}{*}{ Brazil } & Count & 6,557 & 3,844 & 10,401 \\
\hline & $\%$ & 63.0 & 37.0 & 100.0 \\
\hline
\end{tabular}

continue...

VISIT: Who decides about visiting your family and relatives?

\begin{tabular}{|c|c|c|c|c|}
\hline & & Individual decision & Joint decision & Total \\
\hline \multirow{3}{*}{ Central-West } & Count & 1,094 & 1,092 & 2,186 \\
\hline & $\%$ within Central-West & 50.0 & 50.0 & 100.0 \\
\hline & $\%$ within Brazil & 20.7 & 21.6 & 21.1 \\
\hline \multirow{3}{*}{ North } & Count & 852 & 877 & 1,729 \\
\hline & $\%$ within North & 49.3 & 50.7 & 100.0 \\
\hline & $\%$ within Brazil & 16.1 & 17.3 & 16.7 \\
\hline \multirow{3}{*}{ Northeast } & Count & 1,148 & 798 & 1,946 \\
\hline & $\%$ within Northeast & 59.0 & 41.0 & 100.0 \\
\hline & $\%$ within Brazil & 21.7 & 15.8 & 18.8 \\
\hline \multirow{3}{*}{ South } & Count & 1,104 & 1,226 & 2,330 \\
\hline & $\%$ within South & 47.4 & 52.6 & 100.0 \\
\hline & $\%$ within Brazil & 20.9 & 24.2 & 22.5 \\
\hline \multirow{3}{*}{ Southeast } & Count & 1,091 & 1,069 & 2,160 \\
\hline & $\%$ within Southeast & 50.5 & 49.5 & 100.0 \\
\hline & $\%$ within Brazil & 20.6 & 21.1 & 20.9 \\
\hline \multirow{2}{*}{ Brazil } & Count & 5,289 & 5,062 & 10,351 \\
\hline & $\%$ & 51.1 & 48.9 & 100.0 \\
\hline
\end{tabular}

continue... 
FOOD: Who decides about daily food?

\begin{tabular}{llccr}
\hline & & Individual decision & Joint decision & Total \\
\hline \multirow{3}{*}{ Central-West } & Count & 1,954 & 220 & 2,174 \\
& \% within Central-West & 89.9 & 10.1 & 100.0 \\
& \% within Brazil & 21.4 & 17.5 & 21.0 \\
\hline \multirow{3}{*}{ North } & Count & 1,456 & 261 & 1,717 \\
& \% within North & 84.8 & 15.2 & 100.0 \\
\hline \multirow{3}{*}{ Northeast } & \% within Brazil & 16.0 & 20.8 & 16.6 \\
\hline \multirow{3}{*}{ South } & Count & 1783 & 160 & 1,943 \\
& \% within Northeast & 91.8 & 8.2 & 100.0 \\
& \% within Brazil & 19.6 & 12.8 & 18.7 \\
\hline \multirow{3}{*}{ Southeast } & Count & 1,974 & 353 & 2,327 \\
& \% within South & 84.8 & 15.2 & 100.0 \\
& \% within Brazil & 21.7 & 28.1 & 22.4 \\
\hline \multirow{2}{*}{ Brazil } & Count & 1,946 & 260 & 2,206 \\
& \% within Southeast & 88.2 & 11.8 & 100.0 \\
\hline
\end{tabular}

Source: PNDS 2006 (http://bvsms.saude.gov.br/bvs/pnds).

(1) It was used list-wise deletion for missing values in each variable.

Recebido para publicação em 31/10/2012

Aceito para publicação em 19/11/2013 